\title{
Adam Mickiewicz wobec rozwoju cywilizacyjnego i postępu naukowo-technicznego
}

\author{
Adam Mickiewicz about the Development \\ of Civilization and the Progress of Science \\ and Technology
}

\begin{abstract}
Abstrakt
Celem artykułu jest pokazanie stosunku Adama Mickiewicza do problematyki cywilizacyjnej oraz postępu naukowo-technicznego. Pomimo iż generacja pierwszych romantyków polskich (do której należał Mickiewicz) na ogół interesowała się oraz inspirowała artystycznie nauką i techniką, to w polskiej świadomości kulturowej dość mocno zakorzeniło się poczucie antagonizmu pomiędzy „romantycznym” (intuicyjno-emocjonalnym) a naukowym (racjonalno-empirycznym) oglądem świata, w zasadzie wykluczające możliwość ich pogodzenia. W tej perspektywie (zwłaszcza w przekazie popularnonaukowym) romantycy polscy, na czele z Mickiewiczem, wciąż jeszcze jawią się jako niechętni nauce oraz jej sposobom poznawania świata. Artykuł, na przykładzie refleksji cywilizacyjnych Mickiewicza, pokazuje niejednoznaczność i złożoności stosunku romantyków polskich do tych kwestii. Podstawę źródłową niniejszych rozważań stanowią: utwory literackie Mickiewicza (zaginiona Historia przyszłości, a szczególnie jej pierwsza wersja - petersburska) oraz cykl Prelekcji paryskich (zwłaszcza
\end{abstract}


kurs IV). Kontekstowo wspomniano także artykuły prasowe (Wyjątek listu do jednego z redaktorów zamieszczony w „Pielgrzymie Polskim”) oraz listy, jak również rozmowy poety i jego przyjaciół. Materiały źródłowe zostały poddane analizie i interpretacji w świetle ustaleń poczynionych dotychczas w literaturze przedmiotu. W artykule wykorzystano opracowania głównie o charakterze historyczno-literackim, historycznym oraz kulturoznawczym. Zastosowano metodę analizy historyczno-literackiej, z uwzględnieniem szerszego kontekstu historyczno-kulturowego.

Z poczynionych analiz i interpretacji płyną następujące wnioski: Mickiewicz, co najmniej od połowy lat dwudziestych XIX wieku, bacznie przyglądał się przemianom cywilizacyjnym związanym z kolejnymi etapami rewolucji przemysłowej oraz ich wielowymiarowym skutkom, czemu dawał wyraz w swoim piśmiennictwie. Namysł Mickiewicza nad cywilizacją i postępem naukowo-technicznym stanowił składową innych refleksji poety, na przykład tych dotyczących oświeceniowego modelu poznania i wiedzy ludzkiej, czy też cywilizacji zachodnioeuropejskiej - wielkomiejskiej, w której poeta żył. Mickiewicz często łączył swoje refleksje cywilizacyjne również z rozważaniami historiozoficznymi oraz tymi odnoszącymi się do kwestii narodowych. Stosunek poety do postępu cywilizacyjnego nie był jednoznaczny. Według niego zachodzące zmiany dawały zarówno nadzieje związane z przyszłym zastosowaniem wynalazków naukowo-technicznych dla dobra ogółu, jak i budziły niepokój łączący się z przewidywanymi niebezpiecznymi skutkami wielotorowych przemian. Mickiewicz obawiał się przede wszystkim duchowej i moralnej degradacji ludzkości.

Słowa klucze: Adam Mickiewicz, wiek XIX, rozwój cywilizacyjny, postęp naukowo-techniczny, literatura polska

\footnotetext{
Abstract

The aim of the article is to show Adam Mickiewicz's attitude to the problems of civilization and scientific and technological progress. Despite the fact that the generation of the first Polish Romantics (of which Mickiewicz was a member) was generally interested in and artistically inspired by science and technology, a sense of antagonism between the "romantic" (intuitive-emotional) and scientific (rational-empirical) views of the world, which in principle excludes the possibility of reconciliation. In this perspective (especially in popular science), the Polish Romantics, led by Mickiewicz, still appear as reluctant towards science and its ways of learning about the world. Using Mickiewicz's reflections on civilization as an example, the article shows the ambiguity and complexity of the Polish Romantics' attitude to these issues. The sources for this article include Mickiewicz's literary works (the lost Historia przyszłości [History of the Future], especially its first St Petersburg version), the series of
} 
Parisian Lectures (especially Course IV), press articles (An Excerpt from a Letter to one of the Editors published in Pielgrzym Polski), as well as letters and conversations between the poet and his friends. The source materials have been analyzed and interpreted in the context of the findings made so far in the literature on the subject. The article makes use of studies mainly of a historical and literary nature, on top of historical and cultural studies. The method of historical and literary analysis was applied, taking into account the wider historical and cultural context. The following conclusions emerge from the analyses and interpretations made: Mickiewicz, at least since the mid-1820s, closely followed the civilizational changes associated with the successive stages of the Industrial Revolution and their multidimensional effects, which he expressed in his writings. Mickiewicz's reflection on civilization and the scientific and technological progress was a component of the poet's other reflections, including those on the Enlightenment model of cognition and human knowledge, or on Western European civilization, a metropolitan one in which the poet lived. Mickiewicz often combined his reflections on civilization also with historiosophical considerations with those on national issues. The poet's attitude to issues of civilization was not unequivocal. According to him, the changes taking place gave rise both to hopes connected with the future use of scientific and technical inventions for the general good and to anxiety connected with the anticipated dangers of multifaceted transformations. Mickiewicz was primarily concerned about the spiritual and moral degradation of humanity.

Keywords: Adam Mickiewicz, 19th century, civilizational development, scientific and technological progress, Polish literature

Każde odkrycie umystowe jest jeno iskra duchowa, natchnieniem wzwyż

Adam Mickiewicz (Literatura słowiańska)

\section{Mickiewiczowskie wizje przyszłości}

Pokolenie, do jakiego należał Adam Mickiewicz (1798-1855), ukształtowała refleksja oświeceniowa, w której na ogół dominowało optymistyczne przekonanie, iż człowiek za pomocą nauki może racjonalnie opanować i uporządkować otaczający go świat. Z drugiej strony, generację Mickiewiczowską inspirowała również myśl antytechniczna z przełomu XVIII i XIX stulecia, będąca reakcją na rewolucję przemysłową (brzydotę nowych miast przemysłowych, nędzę obszarów miejskich i degradację 
środowiska). Prekursorem tego rodzaju refleksji był Jean-Jacques Rousseau. Z krytycznego stanowiska wobec nauki i jej możliwości wyrosły także refleksje niemieckich „filozofów przyrody” z Friedrichem Wilhelmem Josephem von Schellingiem na czele ${ }^{1}$.

Pomimo iż pokolenie Mickiewiczowskie (generacja pierwszych romantyków polskich) na ogół interesowało się (oraz nierzadko także inspirowało artystycznie) rozwijającą się na ich oczach nauką i techniką, to w polskiej świadomości kulturowej dość mocno zakorzeniło się poczucie antagonizmu pomiędzy „romantycznym” (intuicyjno-emocjonalnym) a naukowym (racjonalno-empirycznym) oglądem świata, w zasadzie wykluczające możliwość ich pogodzenia. W tej perspektywie (zwłaszcza w przekazie popularnonaukowym) romantycy zazwyczaj jawią się jako niechętni, a nawet wrodzy nauce (głównie naukom matematyczno-przyrodniczym) oraz jej sposobom poznawania świata - osławionemu „szkiełku i oku”. A przecież, jak wiadomo, sami romantycy polscy nie tylko nie odwracali się obojętnie od przemian cywilizacyjnych, których byli świadkami, ale na ogół przyglądali się im z uwagą, zaś postrzeganie przez nich owych zmian wcale nie było jednowymiarowe czy jednostronne - czego przykładem jest nie tylko Adam Mickiewicz, ale też inni znakomici romantycy: Juliusz Słowacki, Zygmunt Krasiński czy Cyprian Kamil Norwid ${ }^{2}$.

1 Jak pokazuje historia kultury, w odniesieniu do postępu naukowo-technicznego na przestrzeni wieków przenikały się dwa odmienne stanowiska: $\mathrm{z}$ jednej strony optymizm, zaś z drugiej pesymistyczny krytycyzm (związany z podejściem antytechnicznym i antyindustrializacyjnym). Filozofowie tej miary, co Francis Bacon (1561-1626) czy później Henri de Saint-Simon (1760-1825), a także rówieśnik Adama Mickiewicza Auguste Comte (1798-1858), wierzyli, że poznanie przyrody i sprawowanie nad nią władzy za pośrednictwem techniki przyczyni się do dobrobytu społeczeństwa (Bacon). Jako alternatywę dla dawnego rodzaju społeczeństw przedstawiali społeczeństwo industrialne rządzone przez specjalistów od techniki, przemysłu oraz naukowców (Saint-Simon), pokazując je jako ostatnią - pozytywną fazę rozwoju ludzkości (Comte). Vide: Val Dusek, Philosophy of Technology: An Introduction (Malden: Wiley-Blackwell, 2006), 49 i n.

2 W tym artykule refleksje cywilizacyjne Zygmunta Krasińskiego, Juliusza Słowackiego, Cypriana Kamila Norwida (mające uzasadnienie w literaturze przedmiotu) pozostawiam poza marginesem zainteresowań, skupiając się przede wszystkim na myśli Mickiewicza. Na ten temat por. m. in.: M. Dybizbański, Romantyczna futurologia (Kraków: TPPK, 2005). 
Stosunek Adama Mickiewicza do kwestii cywilizacyjnych nie był jednoznaczny ${ }^{3}$. Przede wszystkim stanowił on część składową innych refleksji (znacznie obszerniejszych) - dotyczących postawy autora wobec oświeceniowego modelu poznania i wiedzy ludzkiej czy też cywilizacji zachodnioeuropejskiej, w której poeta żył, mieszkając między innymi w Paryżu. Mickiewicz i emigranci polscy z jego pokolenia to właśnie z perspektywy paryskiej, „z najdogodniejszego wówczas punktu obserwacyjnego, z Paryża, metropolii nowoczesności", mogli oglądać dziewiętnastowieczny przewrót cywilizacyjny ${ }^{4}$. Zagadnienia te nie były więc dla Mickiewicza ani kwestią teoretyczną, ani odległą. Dla polskiego poety była to sprawa ważna i bliska - bowiem bezpośrednio i niejako na co dzień stykał się on z cywilizacją wielkomiejską oraz z jej problemami. Przy tym pisarz nader często łączył swoje refleksje cywilizacyjne z rozważaniami historiozoficznymi (a także z namysłem nad sprawami narodowymi). Poddając analizie refleksje cywilizacyjne Adama Mickiewicza i jego literackie wizje przyszłości, nie sposób więc oddzielić tych elementów. Na potrzeby niniejszego opracowania skupię się jednak przede wszystkim na aspektach naukowo-technicznych Mickiewiczowskich wyobrażeń.

W perspektywie prezentowanego szkicu najciekawsza w tym względzie wydaje się przede wszystkim zaginiona Historia przyszłości Mickiewicza, a szczególnie jej pierwsza (petersburska) wersja pisana przez poetę w języku francuskim w Rosji wiosną 1829 roku$^{5}$. Utwór ten dziś znany jest głównie z relacji przyjaciela Mickiewicza - poety Antoniego Edwarda Odyńca opublikowanej w jego Listach $z$ podróż $y^{6}$. Pierwsza wersja Historii przyszłości, w przeciwieństwie do kolejnych, zawiera bowiem obraz

3 Obszernie na ten temat wypowiedziałam się w pracy: Monika Stankiewicz-Kopeć, Miasto i cywilizacja $w$ kontekście sporów modernizacyjnych $w$ piśmiennictwie polskim lat 1800-1830 (Kraków: Wydawnictwo Naukowe AIK, 2018), 78-90. Z zawartych tam ustaleń korzystam także w niniejszym artykule.

4 Zofia Stefanowska, „Norwid - pisarz wieku kupieckiego i przemysłowego” w Literatura, komparatystyka, folklor. Księga poświęcona Julianowi Krzyżanowskiemu, red. Maria Bokszczanin, Stanisław Frybes, Edmund Jankowski, (Warszawa: PIW, 1868), 11.

5 Stefania Skwarczyńska, Mickiewicza „Historia przyszłości” i jej realizacje literackie (Łódź: Łódzkie Towarzystwo Naukowe, 1964), 8-10, wspomina o czterech wersjach utworu. Pierwsza - petersburska, pochodząca z 1829 roku - zaginęła. Rękopisy kolejnych wersji miał zniszczyć sam autor. Wersja druga pisana była od roku 1831 (a nawet od 1830); trzecia powstała w latach 1834-1835; zaś czwarta - po 1842 roku. Począwszy więc od roku 1829 aż do roku 1842 Mickiewicz podejmował kolejne próby twórcze w tym względzie.

6 Antoni Edward Odyniec, Listy z podróży (Wybór), wstęp Henryk Życzyński, seria I, nr 117, (Lwów: Wydawnictwo Ossolineum, 1937), 18-21. Utwór Mickiewicza znany jest też ze wzmianek innych przyjaciół poety: np. Józefa Bohdana Zaleskiego (który 
przyszłości oparty głównie na przesłankach naukowo-technicznych. W tej właśnie wersji wyznacznikami przyszłości są: technicyzacja życia oraz stosunek cywilizacji materialnej do kultury duchowej. Pozostałe warianty Mickiewiczowskiej Historii przyszłości - eksponujące raczej kwestie polityczne i społeczne - nie będą przedmiotem niniejszej reflek$\mathrm{sji}^{7}$. Powołując się na rozmowy z Mickiewiczem na temat tworzonej w Rosji Historii przyszłości, Antoni Edward Odyniec w korespondencji z Julianem Korsakiem z 1829 roku (w liście z 9/21 maja) opisał ów futurystyczny utwór poety, prawdopodobnie mający stanowić rodzaj powieści (anty)utopijnej, czy też traktatu historycznego z elementami fantastyki politycznej, naukowej i społecznej.

Jednak już na początku należy zaznaczyć, że jedną kwestią jest to, co we wspomnianym dziełku rzeczywiście pisał sam Mickiewicz, zaś kolejną to, co po kilkudziesięciu latach napisał o tym (wówczas już zaginionym) utworze Odyniec - swoją drogą znany gawędziarz ${ }^{8}$. Jednak, jako że dziś w zasadzie nie istnieje już żadna realna szansa na zweryfikowanie jego relacji, przyjmijmy, iż odnośnie do utworu Mickiewicza Odyniec nie rozminął się z prawdą. Podobnie zresztą zakładają współcześni badacze literatury science fiction - na ogół dający w tej kwestii wiarę Odyńcowym relacjom i na ich podstawie sugerujący, iż dzieło Mickiewicza (gdyby zostało wydane) miało nawet szansę zrewolucjonizować literaturę światową, bowiem wyprzedzało późniejsze wizje takich autorów jak: Juliusz Verne, Herbert George Wells czy Jerzy Żuławski, a nawet, jak twierdzi Antoni Smuszkiewicz, „prześcigało je w naukowo-technicznych i społecznych spekulacjach"'.

Kolejne ważne wypowiedzi poety na temat cywilizacji przyszłości przynosi cykl Mickiewiczowskich wykładów o literaturze

opowiadał, że w roku 1833 miał w ręku rękopis całości). Vide: Władysław Mickiewicz, Żywot Adama Mickiewicza, t. II, (Poznań: Drukarnia „Dziennika Poznańskiego”, 1892), 225.

7 Na temat Historii przyszłości vide: m.in.: Stanisław Pigoń, „Metamorfozy Historii przyszłości", w idem, Zawsze o Nim. Studia i odczyty o Mickiewiczu, (Warszawa: Wydawnictwo Rytm, 1998); Zofia Trojanowiczowa, „Uwagi o Mickiewiczowskich wizjach przyszłości”, w Na początku wieku. Rozważania o tradycji, red. Zofia Trojanowiczowa, Krzysztof Trybuś, (Poznań: PTPN, 2002), 67-72; Dorota Siwicka, „Historia trzeciego tysiąclecia. Kilka pytań do Adama Mickiewicza”, w Na początku wieku. Rozważania o tradycji, 73-81; Antoni Smuszkiewicz, Zaczarowana gra. Zarys dziejów polskiej fantastyki naukowej (Poznań: Wydawnictwo Poznańskie, 1982), 39-42.

8 Na ogół taką opinię o relacjach Odyńca mieli badacze międzywojenni. Vide: Henryk Życzyński, Mickiewicz w oświetleniu Odyńca (Lublin: Towarzystwo Przyjaciół Nauk, 1934), 34.

9 Smuszkiewicz, Zaczarowana gra. Zarys dziejów polskiej fantastyki naukowej, 40-41. 
słowiańskiej - znanych jako Prelekcje paryskie - prowadzonych przez poetę od 22 grudnia 1840 roku do 28 maja $1844 \mathrm{w}$ paryskim Collège de France (zwłaszcza wykłady kursu III i IV). Cykl ten jest krytyczną rozprawą z nowoczesnością. To właśnie wspomniane dzieła Mickiewicza (Historia przyszłości i Prelekcje paryskie) znajdą się w centrum uwagi niniejszego artykułu. O pozostałych wspomniane zostanie jedynie kontekstowo ${ }^{10}$.

Dla porządku, należy jednak przypomnieć, że zainteresowany przemianami cywilizacyjnymi Mickiewicz pozostawił jeszcze inne wizje przyszłości. Jedną z nich jest falsyfikat futurystycznej „Gazety Województwa Szawelskiego", zamieszczony na kartach emigracyjnego czasopisma „Pielgrzym Polski” z dnia 23 czerwca 1833 roku (nr 15) jako Wyjątek listu do jednego $z$ redaktorów ${ }^{11}$. Mickiewicz dał tam wyobrażenie tego, co miało dziać się w Europie u progu XX wieku (tj. w roku 1899). Zawarte tam obrazy przyszłości, tak jak w poprzednim przypadku, również zostały zdeterminowane przez przewidywane wynalazki techniczne i przyszłe osiągnięcia przemysłowe. Dlatego warto o nich wspomnieć w tym miejscu.

W futurystycznej wizji Mickiewicza z kart „Pielgrzyma Polskiego” w Europie u progu XX stulecia po latach wojen zapanuje wreszcie „pokój powszechny" sprzyjający rozwojowi naukowo-technicznemu i przemysłowemu, zaś Polska odzyska upragnioną niepodległość - jako „Rzeczpospolita Syberyjska”. Ten ostatni aspekt miał na celu przede wszystkim pokrzepienie polskiej emigracji, do której skierowane było wspomniane pismo. Tak czy inaczej, w Mickiewiczowskiej wizji postęp naukowo-techniczny miał w efekcie doprowadzić do szybkiego rozwoju miast; także tych polskich, które wyobraźnia poety wyposażyła między innymi w olbrzymie gmachy imponujące swoją wielkością i rozmachem ${ }^{12}$.

10 Prelekcje paryskie mają w Polsce długą tradycję badawczą. Vide: m.in.: Wiktor Weintraub, Poeta i prorok. Rzecz o profetyzmie Mickiewicza (Warszawa: PIW, 1982), 277 i n.; Andrzej Walicki, „Adama Mickiewicza prelekcje paryskie”, w Polska myśl filozoficzna i społeczna, t. I, red. Andrzej Walicki, (Warszawa: Książka i Wiedza, 1973); Bogusław Dopart, „Koncepcja literatury mesjanistycznej w prelekcjach paryskich Adama Mickiewicza”, Ruch Literacki 5-6 (1982); Zofia Stefanowska, „Legenda słowiańska w prelekcjach paryskich", w eadem, Próba zdrowego rozumu. Studia o Mickiewiczu (Warszawa: Oficyna Wydawnicza RYTM, 2001); Michał Kuziak, O prelekcjach paryskich Adama Mickiewicza (Słupsk: Wydawnictwo Naukowe Akademii Pomorskiej w Słupsku, 2007).

11 Był to ostatni zeszyt „Pielgrzyma Polskiego” pod redakcją poety. Adam Mickiewicz, „Wyjątek listu do jednego z redaktorów”, Pielgrzym Polski 15 (1833).

12 Ibidem. 
Po lekturze Wyjątku listu do jednego z redaktorów można odnieść wrażenie, że w przekonaniu Mickiewicza eskalacja postępu naukowo-technicznego i rozwoju przemysłowego, którą przewidywał poeta u progu XX stulecia, wpłynie także na zmianę ówczesnych priorytetów społecznych. Za kilkadziesiąt lat na pierwszym miejscu będzie bowiem stawiana gospodarka oraz napędzające ją nauka i technika. Nie przypadkiem we wspomnianej futurystycznej „Gazecie Województwa Szawelskiego”, której winietę umieścił Mickiewicz w „Pielgrzymie Polskim”, znalazły się w „dziwnym porządku” (to znaczy nie spotykanym za czasów, w których poeta pisał ów Wyjątek listu do jednego z redaktorów): „naprzód wiadomości gospodarskie, potem naukowe, w środku wypadki narodowe, urządzenia etc., etc. na końcu krótki dodatek polityczny - nieciekawy"13. W wyobrażeniu poety zmiana priorytetów wpłynie także na stosunki społeczne w Europie - która skonfederuje się i zdemokratyzuje.

Mimo pojawiających się już w pierwszej wersji Historii przyszłości refleksji o pesymistycznym wydźwięku względem rozwijającej się na oczach poety cywilizacji, w zasadzie można przyjąć, iż do czasu wspomnianej publikacji w „Pielgrzymie Polskim” nie widać jeszcze u Mickiewicza skłonności do degradowania wartości osiągnięć naukowo-technicznych. Tego rodzaju tendencja zaistniała głównie w latach czterdziestych - niewątpliwie pod wpływem towianizmu oraz coraz mocniej doskwierającej poecie (wraz z upływem lat) tęsknoty za Ojczyzną. W związku z gnębiącą go nostalgią, Mickiewicz coraz bardziej negował bowiem stechnicyzowaną rzeczywistość zachodnioeuropejską, a jednocześnie idealizował Ojczyznę, choćby przekonując, iż „kałamaszka litewska bez sprężyn przejmujących ruchy trzęsące wozu, lepsza niż drogi żelazne"14.

Utwory Mickiewicza stanowią interesujące dokumenty świadomości cywilizacyjnej twórcy pierwszej połowy XIX wieku ${ }^{15}$. W tej perspektywie wspomniane dzieła stają się „zwierciadłem” dylematów Mickiewicza;

13 Idem, „Księgi narodu i pielgrzymstwa polskiego. Pisma polityczne z lat 1832-1834”, w idem, Dzieła, t. VI, tłum. pism francuskich Artur Górski, oprac. Leon Płoszewski, (Warszawa: Czytelnik, 1950), 158 i n. Zwróciła na to uwagę Dorota Siwicka, której refleksjom i ustaleniom niniejszy artykuł wiele zawdzięcza, vide: Siwicka, „Historia trzeciego tysiąclecia. Kilka pytań do Adama Mickiewicza".

14 Adam Mickiewicz, „Listy”, w idem, Dzieła, t. XVI, oprac. Leon Płoszewski, (Warszawa: Czytelnik, 1950), 215. List Adama Mickiewicza z 1842 roku.

15 Obszerniej na temat samych Prelekcji paryskich wypowiedziałam się w artykule: Monika Stankiewicz-Kopeć, „Refleksje cywilizacyjne poetów pierwszej połowy XIX wieku - Prelekcje paryskie Adama Mickiewicza", Episteme. Czasopismo naukowo-kulturalne 16 (2012): 191-202. Pojawiające się w dalszych częściach artykułu analizy Prelekcji paryskich stanowią nawiązanie do wspomnianego tekstu. 
jego marzeń, fascynacji, rozterek, a także obaw związanych z rozwojem cywilizacji i technicyzacją świata.

\section{Nadzieje}

Jak już zostało wspomniane, Antoni Edward Odyniec w liście do Juliana Korsaka, napisanym w Petersburgu w maju 1829 roku, opisał swoją rozmowę z Adamem Mickiewiczem dotyczącą tworzonej wówczas przez poetę w języku francuskim Historii przyszłości, którą przyjaciel Mickiewicza nazwał „osobliwszym dziełem”. W czasie rozmowy z Odyńcem poeta miał mieć już „napisanych przeszło 30 arkuszy”. Szczęśliwie Odyniec nie ograniczył się jedynie do wspomnienia o utworze Mickiewicza, ale także zaprezentował jego zawartość ${ }^{16}$. Warto przytoczyć obszerniejsze fragmenty wypowiedzi Odyńca, aby dać wyobrażenie o skali i rozmiarach Mickiewiczowskich pomysłów futurystycznych:

Przejrzałem je tylko przelotem, a on sam odczytał mi niektóre patetyczne ustępy. [...] Opowiadanie zaczyna się od roku 2000 i ma obejmować dwa wieki. [...]. Cała zaś ta historia, jak mówił mi Adam, kończyć ma się na wejściu Ziemi w stosunki z planetami, a to za pomocą balonów, które naówczas mają żeglować po powietrzu, jak dziś okręty po morzu; cała zaś ziemia ma być pokryta siecią kolei żelaznych, które jak wiesz budują się już w Ameryce i zaczynają, na próbę, budować w Anglii, a którym Adam ogromną przepowiada przyszłość, twierdząc że postać świata przemienią. A cóż dopiero mówić o cudach przemysłu, wynalazkach i odkryciach. [...] Boję się dotykać szczegółów, bo czuję, iżbym dzisiaj nie skończył17.

$\mathrm{W}$ dalszych fragmentach swojej relacji podekscytowany Odyniec opisuje przyszłe wynalazki wyobrażone przez Mickiewicza:

Ale jak nie powiedzieć choć słówka o całych flotach skrzydlatych balonów, latających jak w powietrzu żurawie lub gęsi? O całych miastach domów i sklepów budowanych z żelaza na kołach, a pędzących po kolejach żelaznych, ze wszech stron lądu, na wielki jarmark pod Lizboną, dokąd znowu ocean, w olbrzymich okrętach, przynosi płody innych części świata? Jak nie wspomnieć o Archimedesowych zwierciadłach, ustawionych na ogromnych przestrzeniach w ten sposób, że ogniste litery odbite w pierwszym,

16 Pierwodruk listów Odyńca zamieszczała „Kronika Rodzinna” w latach 1867-1878 (z przerwami), osobno zostały one wydane w Warszawie w latach 1875-1878 (t. I-IV).

17 Odyniec, Listy z podróży (Wybór), 18-19. 
w okamgnieniu odbijają się w ostatnim? O teleskopach, przez które z balonu można całą ziemię obejrzeć, a z ziemi widzieć co się dzieje na jej satelitach? O akustycznych przyrządach, za pomocą których, siedząc spokojnie przy kominku w hotelach, można słuchać dawanych w mieście koncertów lub wykładów lekcji publicznych? A wszystko to opisano tak prosto, tak naturalnie, jakby w tym nic nadzwyczajnego nie było. I Adam też na serio utrzymuje, że wszystko być kiedyś może i musi ${ }^{18}$.

W perspektywie niniejszego szkicu drugorzędną kwestią jest to, czy Mickiewicz rzeczywiście samodzielnie „wymyślił” opisane przez Odyńca urządzenia, czy też inspirował się prowadzonymi ówcześnie badaniami i eksperymentami w tych dziedzinach. Chociaż dziś najbardziej prawdopodobna wydaje się ta druga możliwość, to jednak wcale nie umniejsza to wartości futurystycznych wyobrażeń poety, który (jeśli przyjmiemy, że Odyniec pisze prawdę) swoją Historią przyszłości potwierdzał własną przenikliwość i znawstwo współczesnych mu zagadnień naukowo-technicznych. Pokazał, iż jest bystrym komentatorem rzeczywistości, z obserwacji której potrafił wyciągać daleko idące wnioski na przyszłość. Z perspektywy nam współczesnej, w konfrontacji z aktualnymi osiągnięciami naukowo-technicznymi, widać, że przyszłość potwierdziła wiele z przypuszczeń poety.

Dwudziestowieczni badacze literatury polskiej nadawali wspomnianym wizjom Mickiewicza rozmaite kształty. Przykładowo, w ,akustycznych przyrządach", dzięki którym człowiek ze znacznego oddalenia mógł wysłuchiwać miejskich koncertów albo wykładów prowadzonych w odległych od niego instytucjach publicznych, najczęściej dopatrywano się wyobrażenia radia ${ }^{19}$. Innym razem zaś widziano $w$ nich fonograf - urządzenie służące do zapisu i odtwarzania dźwięku (poprzednik gramofonu $)^{20}$. Z kolei w „Archimedesowych zwierciadłach”, błyskawicznie odbijających sygnały świetlne, widziano telewizję, czy też „światłowody”. W tym miejscu nie ma potrzeby kontynuowania tego rodzaju refleksji. Szczególnie ważne wydaje się natomiast, iż Mickiewicz nie tylko przewidział pojawienie się nowych maszyn i urządzeń, ale także dostrzegł istotny związek miedzy osiągnięciami nauki, techniki

18 Ibidem.

19 Juliusz Kleiner zaprzeczał, aby Mickiewicz wyprorokował radio, twierdząc, iż ten pomysł Odyniec z pewnością ściągnął od Verne’a (autora powieści Zamek $w$ Karpatach, popularnej w czasie, gdy ukazywały się Listy z podróży). Vide: Juliusz Kleiner, Mickiewicz, t. II: Dzieje Konrada, cz. 1, (Lublin: TN KUL, 2006), 54.

20 W. Mickiewicz, Żywot Adama Mickiewicza, 593.

21 Vide: Skwarczyńska, Mickiewicza „Historia przyszłości” i jej realizacje literackie, 6. 
i przemysłu a poważnymi przemianami o charakterze społecznym, politycznym, kulturowym czy moralnym (co potwierdzily Prelekcje paryskie).

$\mathrm{W}$ relacji Odyńca przede wszystkim uderzają pełne rozmachu wizje związane z rozwojem komunikacji - stanowiące wyraz marzeń ludzkości o łatwiejszym i szybszym pokonywaniu odległości: za pomocą statków, kolei żelaznej, czy wreszcie balonów. I tak, pisząc o olbrzymich statkach o wielkiej ładowności, Mickiewicz zwrócił uwagę na przyszły rozwój komunikacji wodnej ${ }^{22}$. Oczywiście, w roku 1829 poeta miał już pewne realne podstawy, aby tak sądzić. Przeszło dwie dekady wcześniej (latem 1807 roku) amerykański inżynier Robert Fulton zbudował (na bazie pomysłów Johna Fitcha) pierwszy pasażerski statek parowy - „Clermont”, a w następnych latach (1812-1814) skonstruował pierwszy okręt o napędzie parowym. W kolejnych latach pojawiały się statki o coraz większych rozmiarach i ładowności. Od roku 1807, czyli od czasu skonstruowania sześćdziesięciotonowego „Clermonta”, długiego na 40 metrów, w ciągu następnego półwiecza rozmiary statku parowego wzrosły kilkakrotnie. Transatlantyk „Great Western” (1838) miał 72 metry długości, zaś ukończony w 1858 roku legendarny żelazny kolos „Great Eastern” (zaopatrzony w silniki o mocy ponad 1000 koni mechanicznych) - najwspanialsze dzieło Isambarda Kingdoma Brunela - posiadał już pokład długości 220 metrów $^{23}$. Dzięki tego rodzaju konstrukcjom i wynalazkom dokonywano ważnych zmian w dziedzinie transportu wodnego. Z czasem znacznie zmniejszył się także czas trwania wypraw morskich. W okresie młodości Mickiewicza, w 1819 roku, pierwszy statek pasażerski z napędem parowym (a właściwie żaglowo-parowym) - bocznokołowiec „Savannah” (prekursor przyszłych transatlantyków) - odbył podróż przez Ocean Atlantycki w 29 dni i 11 godzin ${ }^{24}$. Kilkadziesiąt lat później, już po śmierci poety, w roku 1866 taka podróż skróciła się do około $10 \mathrm{dni}^{25}$. Obserwując współczesną mu rzeczywistość, Mickiewicz miał więc pewne realne podstawy, aby w związku z rozwijającą się na jego oczach nauką i techniką (głównie w związku z zastosowaniem maszyny parowej) myśleć o przyszłym opanowaniu przez człowieka rzek, mórz i oceanów jako ważnych dróg komunikacyjno-handlowych. Chociaż z drugiej strony, jeszcze pod koniec lat dwudziestych XIX stulecia, w czasach, kiedy poeta

22 Siwicka, „Historia trzeciego tysiąclecia. Kilka pytań do Adama Mickiewicza”, 76-77.

23 Witold J. Urbanowicz, Transatlantyki: zarys ich dziejów i techniki (Gdańsk: Wydawnictwo Morskie, 1977), 19 i n., 35 i n.

24 Ibidem, 19-20.

25 Dane podaję za: Lewis Mumford, Technika a cywilizacja. Historia rozwoju maszyny i jej wpływ na cywilizacje, tłum. Ewa Danecka, (Warszawa: PWN, 1966), 176. 
pisał swoje dzieło, idea szybkiego przebycia oceanu (z pomocą maszyny parowej) w wielu kręgach (w tym także i naukowych) nadal wywoływała sceptycyzm ${ }^{26}$.

Z relacji Odyńca wynika, że Mickiewicz już w roku 1829 był przekonany także o przyszłym galopującym rozwoju kolei żelaznych („cała ziemia ma być pokryta siecią kolei żelaznych”); poeta ponoć twierdził, że kolej „przemieni przyszłość świata”. Przypomnijmy, w okresie, w którym Mickiewicz pisał pierwszą wersję Historii przyszłości, już od czterech lat w Anglii funkcjonowała linia kolejowa Darlington-Stockton, uruchomiona we wrześniu 1825 roku, zaś w październiku roku 1829 odbyły się słynne zawody lokomotyw (Rainhill Trials), w których czterotonowa lokomotywa parowa („Rocket”), zaprojektowana przez ojca brytyjskich kolei parowych inżyniera George’a Stephensona, pędząc z imponującą jak na owe czasy prędkością $48 \mathrm{~km} / \mathrm{h}$, odniosła spektakularne zwycięstwo. Jesienią następnego roku (15 września 1830), miało miejsce oficjalne otwarcie linii kolejowej Liverpool-Manchester. Od owego wydarzenia zwykło się datować początek ery kolei na świecie ${ }^{27}$. Wraz z rozwojem komunikacyjnym przekształceniu uległo pojmowanie podstawowych kategorii, głównie czasu i przestrzeni. Stephensonowska „Rocket”, zdolna do pokonania w godzinę $48 \mathrm{~km}$, a potem kolejne, coraz szybsze lokomotywy i inne nowoczesne środki transportu, skracając znacznie czas podróżowania, sprawiały, że czas i przestrzeń zdawały się kurczyć.

Dziś trudno przecenić skalę zmian, jakie spowodowała kolej żelazna w życiu społecznym, gospodarczym i obyczajowym XIX wieku, jednak w czasach, kiedy poeta snuł swoje wizje, wciąż jeszcze najpopularniejszym środkiem lokomocji i transportu lądowego był dyliżans ${ }^{28}$. Wielu współczesnych Mickiewiczowi przekreślało szanse kolei w rywalizacji z pojazdami konnymi; jednak aby naprawdę uwierzono w potęgę kolei, musiały minąć kolejne lata i dziesięciolecia. Nawet kolei zbudowanej w 1837 roku między Paryżem a Saint-Germain-en-Laye długo nie traktowano poważnie: przez lata uchodziła ona jedynie za „zabawkę dla Paryżan” - jak mawiał Louis Adolphe Thiers. Prawdziwa kolejowa hossa miała dopiero się pojawić.

26 Vide: m.in.: Urbanowicz, Transatlantyki: zarys ich dziejów i techniki, 24; Antoni Mączak, Peregrynacje, wojaże, turystyka (Warszawa: Czytelnik, 1984), 221.

27 Vide: Mieczysław Żywczyński, Historia powszechna 1789-1870 (Warszawa: PWN, 2006), 202-203. Wykres pokazujący tempo wzrostu komunikacji pasażerskiej w Anglii, Szkocji, Irlandii w latach 1842-1913 przedstawił Mączak, Peregrynacje, wojaże, turysty$k a, 255$.

28 Swoisty klimat dyliżansowych wypraw oddają powieści młodszego o czternaście lat od Mickiewicza Charlesa Dickensa (m.in. Dawid Copperfield i Klub Pickwicka). 
Jednak największe nadzieje komunikacyjne wiązał Mickiewicz z balonami - spektakularnym wynalazkiem czasów oświecenia. Poetę żywo zajmowały przyszłe podróże podniebne, a nawet międzyplanetarne, możliwe, jego zdaniem, właśnie dzięki zastosowaniu balonów. A swoją drogą, poetyckie marzenia o podbiciu kosmosu za pomocą balonów w zasadzie nie były wówczas już niczym nowym; wszak już w 1785 roku ksiądz Dymitr Michał Krajewski wysłał na księżyc bohaterów swojej fantastycznej powieści Wojciech Zdarzyński. Życie i przypadki swoje opisujący, właśnie „banią powietrzną”.

Niedługo po dokonaniu przez braci Montgolfier, francuskich pionierów lotów balonem, pierwszych udanych prób $\mathrm{z}$ balonami na ogrzewane powietrze (1782), wzloty balonowe (początkowo bezzałogowe) urządzano $\mathrm{w}$ wielu miastach europejskich - w tym także i w Polsce (m.in. w Warszawie w roku 1789). Nic zatem dziwnego, że niebawem nowy fascynujący wynalazek niebawem „wylądował" także i w literaturze polskiej ${ }^{29}$. W czasach oświecenia wzlatująca nad ziemią bania powietrzna stała się symbolem nieograniczonych możliwości ludzkiego rozumu. Snuto barwne domysły na temat przyszłości żeglugi powietrznej oraz możliwości, jakie otwierała ona przed ludzkością. Przy tym jednak ówczesne balony zawodziły jako środek komunikacji - pozbawione możliwości sterowania nimi, zdane były na łaskę i niełaskę wiatrów. Toteż w głowach uczonych, konstruktorów i poetów raz po raz pojawiały się mniej lub bardziej spektakularne rozwiązania dotyczące sterowania balonem ${ }^{30}$.

W pierwszej wersji Historii przyszłości Mickiewicz snuł wizję roku 2000, w którym spodziewał się użycia „floty skrzydlatych balonów latających jak żurawie lub gęsi”. Dwa wieki później (tj. około roku 2200) przewidywał wejście Ziemi w stosunki z innymi planetami - właśnie przy użyciu balonów ${ }^{31}$. Tym samym Mickiewicz sugerował, iż w wyniku intensywnych przemian cywilizacyjnych związanych z rozwojem naukowo-technicznym wiek XXI będzie erą pojazdów powietrznych, które

29 Wśród oryginalnych i tłumaczonych polskich utworów „balonowych” końca XVIII stulecia znalazły się m.in.: oda Adama Naruszewicza Balon (przypisywana niegdyś Stanisławowi Trembeckiemu), wiersz Trembeckiego Do Wojciecha Miera bawiącego na wsi, żartobliwy epigramat Na podróż Blancharda, poematy Franciszka Dionizego Kniaźnina Balon, czyli wieczory oraz Gala - Wielka, czyli przydatek do „Balonu”, czy wiersz Piotra Tyszyńskiego Bania powietrzna, powieść księdza Michała Dymitra Krajewskiego z roku 1785 Wojciech Zdarzyński życie i przypadki swoje opisujący.

30 Vide: Irena Stasiewiczowa, Bolesław Orłowski, „Balony polskie w XVIII wieku”, Studia i materiały z dziejów nauki polskiej 2 (1960), 43 i n.

31 Gdyby poeta dokończył i wydał swoją Historię przyszłości, swoimi balonowymi wizjami wyprzedziłby Edgara Allana Poe, autora słynnej Bujdy balonowej (1844), oraz Juliusza Verne’a, autora Pięciu tygodni w balonie (1863). 
z czasem podbiją także i kosmiczne przestrzenie. Marzenia o podniebnym podróżowaniu za pomocą nowoczesnego balonu (którym można sterować) nie opuszczały autora Historii przyszłości aż do jego śmierci w 1855 roku. 27 września 1852 roku poeta przedstawił swojemu przyjacielowi Aleksandrowi Chodźce udoskonalony przez siebie projekt balonu. W swoim notatniku (Apomnemoneumata) Chodźko zanotował następujące słowa wypowiedziane wówczas przez Mickiewicza:

Balon już podniósł machinę parową. Wielki krok na drodze wynalezienia kierunku. Trzeba brzuch balonowy zniszczyć, inaczej nie da się kierować. Oto mój projekt. Trzy, może więcej, kiszki nadęte gazem, we środku trzy soupapes [tj. wentyle - M.S.K.], które zrobią, że nawet w przypadku rozdarcia się jednej części gaz w innych częściach zostanie i przypadki usuwa. Łódź ze sternikiem w środku; na niej mała machina parowa, do wyrzucania z rury szufla, na którego końcu parasol. Ten ostatni, rozwijający się pchnięciem pary i oną ciągnięty, sprawi próżnię w powietrzu i spowoduje potrzebny ruch, a zatem poruszy balonem ${ }^{32}$.

W spierając się własnymi rysunkami („balonu i rury z parasolem”) 33, Mickiewicz skrupulatnie objaśniał zasady działania tego rodzaju nowoczesnego balonu:

Parasol, pchnięty parą w kierunku A-B, wyleci w powietrze zamknięty, potem pchnięty w kierunku B-A, otworzy się i będzie parł kolumnę powietrza C, D, E, F. Teraz idzie o urządzenie rury parasolowej i zastosowanie do niej działania pary ${ }^{34}$.

Wskazując na swoje odręczne szkice, Mickiewicz tłumaczył Chodźce:

Punkt środkowy czarny wskazuje miejsce łodzi. Każda z kiszek będzie miała we środku soupapesa, otwierające się parciem gazu, póki kiszka niepełna i stojące nieruchomie, skoro się kiszka napełni gazem ${ }^{35}$.

32 Adam Mickiewicz, „Rozmowy z Adamem Mickiewiczem”, w idem, Dzieła wszystkie, t. XVI, oprac. Stanisław Pigoń, wstęp Władysław Mickiewicz, (Warszawa: Kasa im. Józefa Mianowskiego, 1933), 237.

33 Ibidem, 237. Jak wyjaśnia międzywojenny wydawca Dzieł wszystkich Mickiewicza: „według prymitywnego autografu oba rysunki odtworzył T. Niesiołowski”.

34 Ibidem, 237.

35 Ibidem. 
Dalej poeta przewidywał:

Kiedyś może się ta sztuka tyle wydoskonalić, że parowa machina będzie latać na własnych skrzydłach, bez balonu. Powietrze jest naturalnym polem komunikacji, gdzie nie przeszkadza i nic nie wstrzymuje. Balon będzie użyteczny, jak pęcherz w brzuchu ryby dla pomocy machinie pływania w powietrzu, ale machina będzie mogła obyć się bez niego. Wynalazek ten jest bliski odkrycia ${ }^{36}$.

Marzenia konstruktorów, naukowców i poetów o udoskonalonym balonie-sterowcu, na dobrą sprawę stały się rzeczywistością dopiero w ostatnich dekadach XIX stulecia: w roku 1884 sterowiec „La France”, posiadający silnik elektryczny oraz śmigło, podjął swój pierwszy lot zakończony sukcesem - z załogą na pokładzie. Tych czasów Mickiewicz jednak już nie dożył.

\section{Obawy}

Obok tego rodzaju pełnych optymizmu wyobrażeń związanych z rozwojem nauki i techniki, w refleksji Mickiewicza można także zauważyć w zasadzie już od końca lat dwudziestych - pojawiające się (i sukcesywnie narastające) przemyślenia o wydźwięku pesymistycznym, związane z przeczuciem zmierzchu cywilizacji Zachodu. Zresztą, zwraca na to uwagę cytowany już Antoni Edward Odyniec, odnosząc się do pierwszej wersji Historii przyszłości ${ }^{37}$. Krytykę cywilizacji zachodniej (przemysłowej, burżuazyjnej) niosą także słynne Księgi narodu polskiego i pielgrzymstwa polskiego (wydane w 1832 roku) ${ }^{38}$.

Tego rodzaju przekonania poety zintensyfikowały się jednak i doszły do głosu w sposób szczególny w latach czterdziestych w Prelekcjach paryskich (zwłaszcza w kursie IV). Mickiewicz, podejmując wspomniane wykłady z literatur słowiańskich w paryskim Collège de France, zwracał uwagę, że jego celem jest „rozważenie stosunków cywilizacji słowiańskiej i zachodniej oraz ich wzajemnych wpływów"39. Przy tym poeta,

36 Ibidem, 238.

37 Odyniec, Listy z podróży (Wybór), 18.

38 Adam Mickiewicz, Pisma filomackie. Pisma polityczne z lat 1832-1834, w idem, Dzieła, t. VI, oprac. Leon Płoszewski et al., (Warszawa: Czytelnik, 1950).

39 Adam Mickiewicz, „Literatura słowiańska: kurs I”: w idem, Dzieła, t. VIII, oprac. Leon Płoszewski, oprac. Leon Płoszewski et al., (Warszawa: Czytelnik, 1950), 24. 
eksponując schyłkowy, dekadencki charakter współczesnej cywilizacji Zachodu, jednocześnie podkreślał wyraźne analogie pomiędzy stanem owej cywilizacji a sytuacją cywilizacji starożytnych (zwłaszcza rzymskiej) z okresu ich schyłku i upadku.

Mickiewicz, żyjąc wówczas w Paryżu, obserwując współczesną mu cywilizację przemysłową, w swoich „prelekcjach” przekonywał o swoistym „wyczerpaniu” jego epoki - o „braku siły zdolnej wzniecić w ludziach uczucia”, braku „natężenia życia”, braku „,iskry moralnej”. Tego rodzaju przekonanie pojawiło się na przykład w jego styczniowym wykładzie z roku 1844 (wykład 9) ${ }^{40}$. Jednak pomimo tego rodzaju przeświadczeń, poeta nie pogrążył się w pesymizmie, wierzył bowiem w przyszłe odrodzenie, które, w jego przekonaniu, współczesna cywilizacja będzie zawdzięczała Słowianom ${ }^{41}$.

Przede wszystkim wierzył jednak w Opatrzność i jej ingerencję w losy ludzkości. Warto w tym względzie przypomnieć jedną z nieco późniejszych rozmów, jakie na początku lat pięćdziesiątych przeprowadził poeta z Aleksandrem Chodźką. Otóż Mickiewicz, zwierzając się przyjacielowi ze swoich obaw cywilizacyjnych, jednocześnie wprost wyraził swoją nadzieję w ingerencję Opatrzności, która, jego zdaniem, nie pozwoli na całkowitą degradację i zagładę ludzkości - po prostu nie objawiając ludziom zbyt wcześnie kolejnych tajników nauki. Dotąd, dopóki „nie udoskonali się pewna ilość moralności w masach. [...] Tak Rzymianom nie objawiono prochu, bo zniszczyliby świat" - miał mówić poeta ${ }^{42}$.

Wracając do Prelekcji paryskich, najlepiej pokazujących ówczesny stosunek Mickiewicza do cywilizacji przemysłowej oraz związanych z nią do wynalazków i odkryć naukowych, należy podkreślić, że poeta, głosząc wykłady z paryskiej katedry, przekonywał swoich słuchaczy, że wspomniane dokonania $\mathrm{w}$ istocie nie są dziełem rozumu, ale ducha, rodząc się „poza obrębem rachub rozumowych”. Jak mówił Mickiewicz podczas wykładu 21 maja 1844 roku (cykl czwarty Prelekcji paryskich): „Każde odkrycie umysłowe jest jeno iskrą duchową, natchnieniem wzwyż"43. W trakcie wspomnianego wykładu zgromadzeni w sali słuchacze mogli usłyszeć także Mickiewiczowską krytykę wąsko wyspecjalizowanej współczesnej nauki zachodniej (pogrążonej w „drobiazgowych szczegółach”), pozbawionej głębszej refleksji kulturowej i filozoficznej.

40 Ibidem, 327-328.

41 Adam Mickiewicz: „Literatura słowiańska: kurs III i IV”, w idem, Dzieła, t. XI, oprac. Leon Płoszewski (Warszawa: Czytelnik, 1950), 451.

42 W. Mickiewicz, Rozmowy z Adamem Mickiewiczem, 238.

43 Mickiewicz, „Literatura słowiańska: kurs III i IV”, 452. 
Mickiewicz określił ją mianem „nauki urzędowej”, zwracając uwagę na jej „bezpłodność” i szkodliwość społeczną ${ }^{44}$. Tym samym polski poeta podkreślał konieczność włączenia nauki w sferę ducha, które to pojęcie (inspirowane myślą Augusta Cieszkowskiego) odgrywało rolę szczególną w refleksji Mickiewicza z lat czterdziestych. W jego przekonaniu tylko taka nauka poprowadzi ludzkość „,naprzód” - „ku Bogu” - o czym mówił poeta do swoich słuchaczy na jednym z czerwcowych wykładów 1843 roku. ${ }^{45}$ Według Mickiewicza, tylko tego rodzaju nauka mogła mieć zbawienny wpływ na współczesną cywilizację. Tymczasem, nauka zachodnia, która w przekonaniu poety poszła w stronę „nauki urzędowej”, zatraciła zdolność do rewitalizacji cywilizacji Zachodu. W tym względzie ratunek dla odrodzenia tej cywilizacji widział Mickiewicz w Słowianach, których nauka nie została jeszcze skażona „urzędowością", nie zatraciła związku z „duchem”: „we wszystkich dziedzinach oddzielili [Słowianie M.S.K.] naukę natchnioną, czyli intuicyjną, od nauki wyuczonej, czyli urzędowej"46 - mówił poeta.

W pierwszej połowie lat czterdziestych Mickiewicz swoje poglądy cywilizacyjne głosił jednak nie tylko z katedry Collège de France - dzielił się nimi również w innch kręgach. Ślady tego rodzaju refleksji pojawiają się w ówczesnych improwizacjach poety, skupiających uwagę jego najbliższego otoczenia. Jedną z takich improwizacji (prawdopodobnie mającą miejsce w roku 1842) przypomniał syn poety, Władysław Mickiewicz, w swoich wspomnieniach spisanych po francusku Mélanges posthumes d'Adam Mickiewicz (wydanych w 1872 roku). Według relacji syna, Adam Mickiewicz dał wówczas wyobrażenie nowoczesnego miasta przyszłości - metropolii trzeciego tysiąclecia. Ta urbanistyczna wizja poety - tyleż groteskowa, co niepokojąca - daje wyraz ówczesnym obawom pisarza związanym z wytworzeniem się w przyszłości „sztucznej cywilizacji”, która, odizolowując człowieka od świata natury, w efekcie zdegraduje go duchowo i moralnie, stępi jego wrażliwość, ograniczy horyzonty myślowe, rozluźni więzi międzyludzkie i pogrąży w materializmie ${ }^{47}$.

Opisane przez Władysława Mickiewicza miasto przyszłości, wyłaniające się z wizjonerskiej improwizacji jego ojca, przysłaniał gigantyczny dach, który, chroniąc mieszkańców miasta od niedogodnych czynników atmosferycznych, jednocześnie izolował ich od natury - od nieba, gwiazd,

44 Ibidem, 318-319, 453.

45 Ibidem, 453.

46 Ibidem, 453-454.

47 Mickiewicz Władysław, Mélanges posthumes d’Adam Mickiewicz (Paryż: Libraire du Luxembourg, 1872), 156-157. 
słońca, przyrody. Nakryta swoistym „kloszem” sztuczna metropolia przyszłości, pojawiająca się w improwizacji Mickiewicza, była zaopatrzona we wszelkie wynalazki i udogodnienia cywilizacyjne: posiadała sztuczne ogrzewanie, takież oświetlenie, drewniane podłogi. Chociaż wszystko to zapewniało mieszkańcom tego sztucznego świata wygodę i komfort życia, to przy tym jednak sprawiało, że byli oni zupełnie odizolowani od natury - zamknięci dosłownie „pod kloszem”. Naturę mogli podziwiać tylko nieliczni (na przykład uczeni), a także ci, którym przez przypadek udało się uzyskać dostęp do niej; tak jak pewnemu zamożnemu lordowi angielskiemu, który uchronił dla siebie niewielki skrawek wiejskiej łąki położonej na wyspie, a także... jedną świnię ${ }^{48}$.

Wspomniana przez syna poety paryska improwizacja Adama Mickiewicza, pochodząca z początku lat czterdziestych (poniekąd inspirowana poglądami Jana Jakuba Rousseau o konieczności powrotu do natury), jest krytyką takiego modelu świata komfortowego, w stronę którego dążyła ludzkość współczesna Mickiewiczowi. Tego rodzaju świat budził niepokój w poecie, przewidującym zbyt wysoką cenę, jaką przyjdzie zapłacić ludzkości za życie pełne cywilizacyjnych udogodnień. Ceną tą były właśnie: wspomniana już degradacja duchowa ludzkości, a także osłabienie więzi międzyludzkich - swoiste „poróżnienie moralne”, „rozbicie” (ze względu na brak „ducha”, posiadającego walor integracyjny) i to zarówno w perspektywie indywidualnej, jak też narodowej i międzynarodowej. Wspominał o tym poeta w jednym z wykładów wygłoszonych w Collège de France w ostatnich dniach grudnia, u schyłku roku 1843 (wykład z 26 grudnia, kurs IV) ${ }^{49}$. Mickiewicz przewidywał, iż w przyszłości ludzie, pomimo dysponowania coraz nowocześniejszymi narzędziami ułatwiającymi życie i komunikowanie, w gruncie rzeczy oddalą się od siebie - zatracając ducha (ową „iskrę moralną”), a także niebezpiecznie rozluźnią łączące ich dotychczas więzi. W przekonaniu poety, aby ludzkość odniosła rzeczywiste wielowymiarowe i długodystansowe korzyści z odkryć naukowych i wynalazków cywilizacyjnych, jednocześnie musi rozwijać się moralnie i duchowo.

\section{Zakończenie}

Adam Mickiewicz, co najmniej od połowy lat dwudziestych XIX wieku, bacznie przyglądał się aktualnym przemianom cywilizacyjnym,

48 Ibidem.

49 Mickiewicz, „Literatura słowiańska: kurs III i IV”, 321. 
związanym z kolejnymi etapami rewolucji przemysłowej, oraz ich wielowymiarowym skutkom, czemu dawał wyraz w swojej twórczości i w rozmaitych wypowiedziach. Namysł Mickiewicza nad cywilizacją i postępem naukowo-technicznym stanowił składową innych refleksji poety, między innymi tych dotyczących oświeceniowego modelu poznania i wiedzy ludzkiej, czy też cywilizacji zachodnioeuropejskiej - wielkomiejskiej. W przekonaniu Mickiewicza, zachodzące zmiany niosły zarówno nadzieje związane z przyszłym zastosowaniem wynalazków naukowo-technicznych dla dobra ogółu, jak i z niepokojem łączącym się z przewidywanymi niebezpiecznymi skutkami wielotorowych i wielowymiarowych przemian. Przy czym polski poeta najbardziej obawiał się duchowej i moralnej degradacji ludzkości.

\section{Bibliografia}

\section{Książki i monografie}

Dusek Val, Philosophy of Technology: An Introduction (Malden: Wiley-Blackwell, 2006).

Kleiner Juliusz, Mickiewicz, t. II: Dzieje Konrada, cz. 1, (Lublin: TN KUL, 2006).

Kuziak Michał, O prelekcjach paryskich Adama Mickiewicza (Słupsk: Wydawnictwo Naukowe Akademii Pomorskiej w Słupsku, 2007).

Mickiewicz Adam, Dzieła, t. VI, VIII, XI, XVI, oprac. Leon Płoszewski, (Warszawa: Czytelnik, 1950).

Mickiewicz Adam, „Rozmowy z Adamem Mickiewiczem”, w idem, Dzieła wszystkie, t. XVI, oprac. Stanisław Pigoń, wstęp Władysław Mickiewicz, (Warszawa: Kasa im. Józefa Mianowskiego, 1933).

Mickiewicz Władysław, Mélanges posthumes d’Adam Mickiewicz (Paryż: Libraire du Luxembourg, 1872).

Mickiewicz Władysław, Żywot Adama Mickiewicza, t. II, (Poznań: Drukarnia „Dziennika Poznańskiego”,1892).

Mumford Lewis, Technika a cywilizacja. Historia rozwoju maszyny i jej wpływ na cywilizacje, tłum. Ewa Danecka, (Warszawa: PWN, 1966).

Odyniec Antoni Edward, Listy z podróży (Wybór), wstęp Henryk Życzyński, seria I, nr 117, (Lwów: Wydawnictwo Ossolineum, 1937).

Pigoń Stanisław, Zawsze o Nim. Studia i odczyty o Mickiewiczu (Warszawa: Wydawnictwo Rytm, 1998).

Siwicka Dorota, „Historia trzeciego tysiąclecia. Kilka pytań do Adama Mickiewicza”, w Na początku wieku. Rozważania o tradycji, red. Zofia Trojanowiczowa, Krzysztof Trybuś, (Poznań: PTPN, 2002), 73-81.

Skwarczyńska Stefania, Mickiewicza „Historia przyszłości” i jej realizacje literackie (Łódź: Łódzkie Towarzystwo Naukowe, 1964). 
Smuszkiewicz Antoni, Zaczarowana gra. Zarys dziejów polskiej fantastyki naukowej (Poznań: Wydawnictwo Poznańskie, 1982).

Stankiewicz-Kopeć Monika, Miasto i cywilizacja w kontekście sporów modernizacyjnych w piśmiennictwie polskim lat 1800-1830 (Kraków: Wydawnictwo Naukowe AIK, 2018).

Trojanowiczowa Zofia, „Uwagi o Mickiewiczowskich wizjach przyszłości”, w $\mathrm{Na}$ poczatku wieku. Rozważania o tradycji, red. Zofia Trojanowiczowa, Krzysztof Trybuś, (Poznań: PTPN, 2002), 67-72.

Walicki Andrzej, „Adama Mickiewicza prelekcje paryskie”, w Polska myśl filozoficzna i społeczna, t. I, red. Andrzej Walicki, (Warszawa: Książka i Wiedza, 1973), 216-272.

Weintraub Wiktor, Poeta i prorok. Rzecz o profetyzmie Mickiewicza (Warszawa: PIW, 1982).

Zofia Stefanowska, „Legenda słowiańska w prelekcjach paryskich”, w eadem, Próba zdrowego rozumu. Studia o Mickiewiczu (Warszawa: Oficyna Wydawnicza RYTM, 2001).

Życzyński Henryk, Mickiewicz w oświetleniu Odyńca (Lublin: Towarzystwo Przyjaciół Nauk, 1934).

Żywczyński Mieczysław, Historia powszechna 1789-1870 (Warszawa: PWN, 2006).

\section{Czasopisma}

Dopart Bogusław, „Koncepcja literatury mesjanistycznej w prelekcjach paryskich Adama Mickiewicza”, Ruch Literacki 5-6 (1982): 225-234.

Stankiewicz-Kopeć Monika, „Refleksje cywilizacyjne poetów pierwszej połowy XIX wieku - Prelekcje paryskie Adama Mickiewicza”, Episteme. Czasopismo naukowo-kulturalne 16 (2012): 191-202.

Stasiewiczowa Irena, Orłowski Bolesław, „Balony polskie w XVIII wieku”, Studia i materiały z dziejów nauki polskiej, seria D: Historia Techniki i Nauk Technicznych 2 (1960): 3-47. 